\title{
An efficient cyanide-degrading Bacillus pumilus strain
}

\author{
Paul R. Meyers, ${ }^{1}$ Pravin Gokool, ${ }^{2}$ Douglas E. Rawlings ${ }^{1}$ and David R. Woods ${ }^{1 *}$ \\ ${ }^{1}$ Department of Microbiology, University of Cape Town, Private Bag, Rondebosch 7700, Cape Town, South Africa \\ ${ }^{2}$ National Chemical Products, PO Box 344, Germiston, 1400, South Africa
}

(Received 30 October 1990; revised I February 1991; accepted 25 February 1991)

\begin{abstract}
A Gram-positive, aerobic, endospore-forming bacterium was isolated by an enrichment technique for the ability to degrade cyanide and was identified as a Bacillus pumilus strain. The bacterium rapidly degraded $100 \mathrm{mg} \mathrm{l}^{-1}$ of free cyanide in the absence of added inorganic and organic substances. The ability to degrade cyanide was linked to the growth phase and was not exhibited before late exponential/early stationary phase. Cyanide-degrading activity could not be induced before this time by the addition of $20 \mathrm{mg}$ cyanide $\mathrm{I}^{-1}$. Production of the cyanide-degrading activity required $0.01 \mathrm{mg} \mathrm{Mn}^{2+} \mathrm{I}^{-1}$ and did not occur at $\mathrm{Mn}^{2+}$ concentrations below $0.002 \mathrm{mg} \mathrm{l}^{-1}$. Cyanidedegrading activity was intracellular and cell-free extracts rapidly degraded cyanide.
\end{abstract}

\section{Introduction}

The current global concern with environmental problems has made the biological detoxification of cyanide an attractive alternative to chemical detoxification procedures. Biological detoxification methods may be both cheaper and more environmentally acceptable than chemical methods. Most attempts to develop biological processes for the detoxification of cyanide-containing effluents from industry have concentrated on cyanidedegrading fungi (Knowles \& Bunch, 1986). ICI Bioproducts markets a product called Cyclear for this purpose (ICI Bioproducts Patent Application, 1987). This is a preparation of cyanide hydratase from a strain of Fusarium lateritium.

However, relatively little work appears to have been done on the characterization and development of bacterial cell-free extracts or enzymes able to degrade cyanide (although Novo-Nordisk A/S has recently filed a patent for the decomposition of metal-cyano complexes using enzymes from a strain of the bacterium Alcaligenes; Novo-Nordisk A/S Patent Application, 1987). The Homestake Mine in Lead, South Dakota, USA, utilizes a biological treatment plant for the detoxification of cyanide-containing wastewaters (Whitlock \& Mudder, 1986). The process involves initial oxidation of free and metal cyanides, as well as thiocyanate, to ammonia and carbonate by a strain of Pseudomonas paucimobilis followed by the oxidation of the ammonia to nitrite and then nitrate by strains of Nitrosomonas and Nitrobacter.
Harris \& Knowles $(1983 a, b)$ and Rollinson et al. (1987) reported the utilization of cyanide as a source of nitrogen by Pseudomonas fluorescens NCIMB 11764. Dorr \& Knowles (1989) described cyanide oxygenase and cyanase activities in this organism. White et al. (1988) reported the conversion of cyanide to formate and ammonia by a pseudomonad isolated from industrial wastewater. Skowronski \& Strobel (1969) isolated a strain of Bacillus pumilus which could survive in solutions of $\mathrm{KCN}$ of up to $2.5 \mathrm{M}$ and grew in media containing $0 \cdot 1 \mathrm{M}-\mathrm{KCN}$ ( $2600 \mathrm{mg} \mathrm{CN}^{-} \mathrm{I}^{-1}$ ). Both living and dead cells decreased the cyanide concentration of this medium, but the dead cells did so to a much smaller extent. The cyanide was degraded to carbon dioxide and ammonia. Castric \& Strobel (1969) and Castric \& Conn (1971) reported the metabolism of cyanide by a growing culture of Bacillus megaterium and proposed the presence of a metabolic pathway involving the condensation of serine with cyanide to form beta-cyanoalanine followed by the hydrolysis of the latter to asparagine and then to aspartic acid. McFeters et al. (1970) studied the effect of cyanide on the respiration and cytochrome content of a highly cyanide-resistant strain of Bacillus cereus. These three Bacillus species were all isolated from the same site, viz. Fargo clay collected from a field near Fargo, North Dakota, USA, which had been cropped in flax for 73 consecutive years (Skowronski \& Strobel, 1969).

We have embarked on a project to assess the potential for the rapid bacterial detoxification of cyanide-containing effluents generated by the mining industry (approxi- 
mately $100 \mathrm{mg} \mathrm{CN}^{-1} \mathrm{1}^{-1}$ ). We report the isolation and characterization of an efficient cyanide-degrading Bacillus pumilus strain.

\section{Methods}

Selection of cyanide-degrading micro-organisms. A continuous selection system was assembled using a stoppered round-bottomed flask into which a small sample of soil material from a cyanide waste water (slimes) dam from a mining company in the Transvaal, South Africa, had been placed. The system was operated at $25^{\circ} \mathrm{C}$. Separate feed solutions containing $10 \mathrm{mg} \mathrm{CN}^{-1} \mathrm{l}^{-1}$ (as NaCN) and tapwater (to supply trace elements) were dripped into the flask at a dilution rate of $0.05 \mathrm{~h}^{-1}$. The pH was not controlled. Filtered air was bubbled through the solution in the flask to aerate it. The overflow from the flask was passed over activated carbon (to trap any micro-organisms washed out of the flask) before passing into a waste drum. The cyanide concentration in the cyanide-containing influent was increased incrementally over 2 months to a final concentration of $100 \mathrm{mg} \mathrm{CN}^{-} \mathrm{I}^{-1}$.

Samples were removed from the flask from time to time and plated onto nutrient agar. A circular piece (diameter $8 \mathrm{~cm}$ ) of Whatman's no. 1 filter paper was placed in the lid of the Petri dish and moistened with $1.5 \mathrm{ml}$ of a $100 \mathrm{mg} \mathrm{l}^{-1}$ solution of $\mathrm{NaCN}(\mathrm{pH} \mathrm{10.5)}$. The plates were sealed with Parafilm and incubated at $30^{\circ} \mathrm{C}$. Bacterial colonies were subcultured on the sealed nutrient agar plates with the cyanide filter paper discs to obtain pure colonies. To test for cyanide degradation, isolated colonies growing on the sealed nutrient agar plates were resuspended in $3 \mathrm{ml}$ sterile distilled water and inoculated into $200 \mathrm{ml}$ screwcap glass bottles containing $100 \mathrm{ml}$ sterile distilled water and $50 \mathrm{mg} \mathrm{CN}^{-} \mathrm{l}^{-1}$ (pH 10.4). The bottles were tightly sealed with screw caps containing rubber seals and incubated at $30^{\circ} \mathrm{C}$ for $14 \mathrm{~d}$. Samples were removed at $24 \mathrm{~h}$ intervals and assayed for residual cyanide. In subsequent experiments with selected strains, $200 \mathrm{ml}$ nutrient broth cultures ( $\mathrm{pH} 7.4$ ) grown at $30^{\circ} \mathrm{C}$ with shaking for $14 \mathrm{~h}$ were harvested by centrifugation and resuspended in $100 \mathrm{ml}$ sterile distilled water and transferred to screwcap bottles. Cyanide (as $\mathrm{KCN}$ ) was added to the cell suspension to a final concentration of $100 \mathrm{mg} \mathrm{CN}^{-} \mathrm{I}^{-1}$ (final $\mathrm{pH}$ 10.5). The bottles were incubated at $30^{\circ} \mathrm{C}$ and assayed for remaining cyanide at half-hourly or hourly intervals.

Determination of residual cyanide. Cyanide-containing solutions were assayed by a modification of the picric acid method of Fisher \& Brown (1952). A linear calibration curve was obtained with the standard cyanide solutions used in the assays. Control experiments involving correlation with a gas chromatography assay indicated that the picric acid test was suitable and reliable. Cyanide-containing solutions $(0.05 \mathrm{ml})$ were added to $0.1 \mathrm{ml}$ of a solution containing $0.5 \%(\mathrm{w} / \mathrm{v})$ picric acid and $0.25 \mathrm{M}-\mathrm{Na}_{2} \mathrm{CO}_{3}$. The resulting solutions were placed in a boiling waterbath for $5 \mathrm{~min}$, diluted to $1 \mathrm{ml}$ with $0.85 \mathrm{ml}$ distilled water, and cooled in tapwater for $30 \mathrm{~min}$ before reading the absorbance at $520 \mathrm{~nm}$ against a blank of distilled water and the picric acid $/ \mathrm{Na}_{2} \mathrm{CO}_{3}$ solution. The absorbance of the cyanide-picric acid reaction product was stable for many hours (Fisher \& Brown, 1952).

Characterization of cyanide-degrading bacteria. Forty-eight bacterial isolates were tested for the ability to degrade free cyanide. The 12 best strains were chosen for further study and characterized with respect to Gram stain, catalase and oxidase reactions, and ability to grow anaerobically. Further characterization was carried out using classification tests described by Gordon (1973), Cruickshank et al. (1975), Norris et al. (1981) and Sneath (1986).

Preparation and assay of cell-free extracts. Nutrient broth cultures $(200 \mathrm{ml})$ grown at $30^{\circ} \mathrm{C}$ with shaking for $14 \mathrm{~h}$ were harvested by centrifugation at $10000 \mathrm{~g}$ for $10 \mathrm{~min}$. Cells were washed twice with
$20 \mathrm{ml}$ ice-cold $50 \mathrm{~mm}$-potassium phosphate $/ 50 \mathrm{~mm}-\mathrm{NaCl}$ buffer, pH 7.4. The cells were finally resuspended in $10 \mathrm{ml}$ ice-cold buffer and disrupted by two passages through an Aminco French pressure cell at $1.1 \times 10^{5} \mathrm{kPa}$. The disrupted cell suspension was centrifuged at $27000 \mathrm{~g}$ for $30 \mathrm{~min}$ at $4{ }^{\circ} \mathrm{C}$. The supernatant was retained and a $2 \mathrm{ml}$ sample, diluted 1 in 20 in $50 \mathrm{~mm}$-potassium phosphate $/ 50 \mathrm{~mm}-\mathrm{NaCl}$

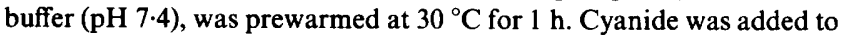
give a final concentration of $102 \mathrm{mg} \mathrm{l}^{-1}$ and triplicate samples $(0.05 \mathrm{ml})$ were assayed for residual cyanide after $0,15,30,60,120$ and $240 \mathrm{~min}$. Protein concentrations in cell-free extracts were determined by the Lowry method.

\section{Results and Discussion}

\section{Isolation and characterization of cyanide-degrading bacteria}

All 12 of the bacterial strains selected for further study were slender, aerobic, Gram-positive, endospore-forming rods. These characteristics are indicative of the genus Bacillus. Spores were located centrally. No vacuolation was visible in cells grown on glucose agar. All 12 strains were unable to hydrolyse starch or reduce nitrate, characteristics which suggested that the organisms were strains of B. pumilus (Knight \& Proom, 1950). Furthermore, all 12 strains exhibited an absolute requirement for biotin for growth on minimal medium. This was taken as confirmation that the 12 isolates were B. pumilus strains.

All 12 isolates grew poorly in aerobic overnight cultures of Difco nutrient broth and cells from such cultures did not degrade cyanide. The same strains grew well under the same conditions in Oxoid nutrient broth and rapidly degraded cyanide (Fig. 1). Studies with

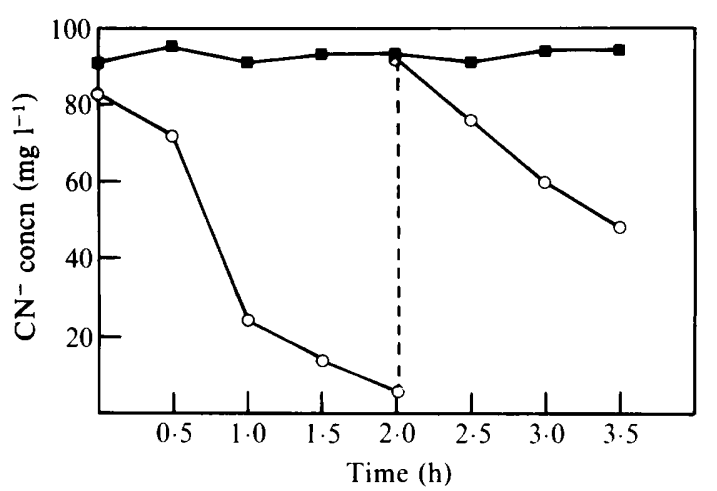

Fig. 1. Cyanide degradation by cells of $B$. pumilus $\mathrm{Cl}$. Cells grown in $200 \mathrm{ml}$ Oxoid nutrient broth at $30^{\circ} \mathrm{C}$ with shaking for $14 \mathrm{~h}$ were harvested by centrifugation and resuspended in screwcap bottles

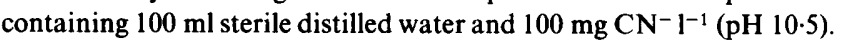
The suspension was incubated at $30^{\circ} \mathrm{C}$ without shaking. The cyanide concentration was assayed at $30 \mathrm{~min}$ intervals for $2 \mathrm{~h}$. After $2 \mathrm{~h}$ an additional $100 \mathrm{mg} \mathrm{CN}^{-} \mathrm{1}^{-1}$ was added and the cyanide concentration determined for a further $2 \mathrm{~h}$. O, Incubation with $B$. pumilus $\mathrm{Cl}$ cells; $\square$, control (cyanide + water). The SEM values were $5-10 \%$ of the values in the Figure (four determinations were done). 

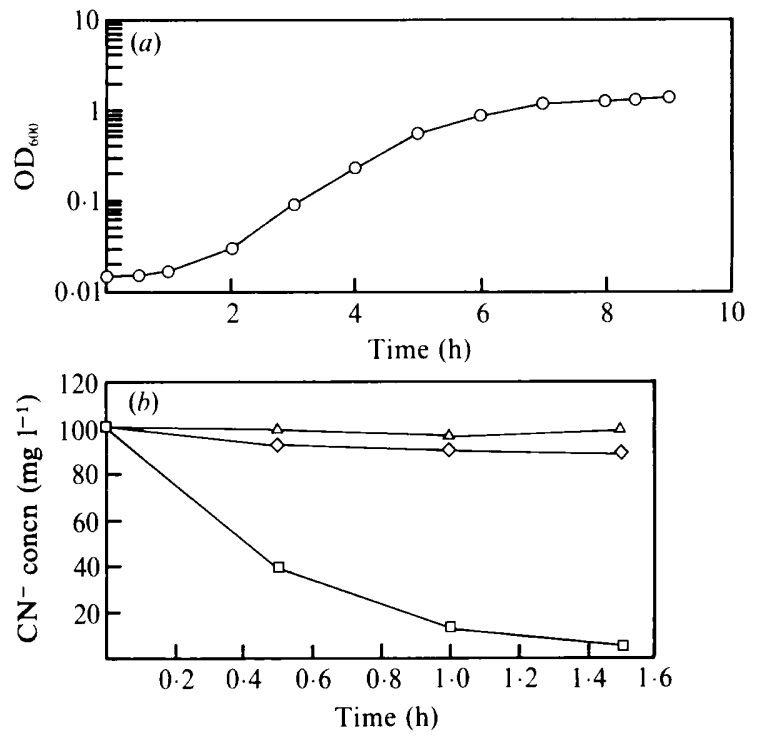

Fig. 2. Relationship between phase of growth and cyanide degradation by cells of $B$. pumilus $\mathrm{Cl}$. Cultures $(200 \mathrm{ml})$ were grown aerobically in Oxoid nutrient broth $(a)$ and cell samples were assayed for cyanide degradation after $2 \mathrm{~h}$ (lag phase, $\triangle$ ), $5.5 \mathrm{~h}$ (mid-exponential phase, $\diamond$ ) and $12.75 \mathrm{~h}$ (stationary phase, $\square)(b)$. The cultures were harvested by centrifugation and resuspended in screwcap bottles containing $100 \mathrm{ml}$ sterile distilled water and $100 \mathrm{mg} \mathrm{CN}^{-} \mathrm{l}^{-1}$ (pH 10.5). The suspensions were incubated at $30^{\circ} \mathrm{C}$ without shaking and the cyanide concentration was assayed at $30 \mathrm{~min}$ intervals for $1.5 \mathrm{~h}$. The SEM values were $5-10 \%$ of the values in the Figure (three determinations were done).

mixtures of Oxoid and Difco nutrient broths indicated that the Difco nutrient broth exerted an inhibitory effect on the aerobic growth and cyanide-degrading ability of these isolates (results not shown). All 12 strains were unable to grow aerobically on minimal agar plates with $\mathrm{KCN}$ as the only nitrogen source using the filter-paper method described by Harris \& Knowles (1983a). The strain which displayed the greatest ability to degrade cyanide was chosen for more detailed study and was designated $B$. pumilus $\mathrm{Cl}$.

\section{Degradation of cyanide by $B$. pumilus $C 1$}

B. pumilus $\mathrm{Cl}$ degraded free cyanide $\left(100 \mathrm{mg} \mathrm{1}^{-1}\right.$, supplied as $\mathrm{KCN}$ ) very efficiently (Fig. 1). The free cyanide was degraded within $2 \mathrm{~h}$ and following the further addition of $100 \mathrm{mg}$ cyanide $\mathrm{l}^{-1}$ the cells continued to degrade the cyanide, albeit at a slower rate. Cells of $B$. pumilus $\mathrm{Cl}$ cultivated in Oxoid nutrient broth and harvested during the lag or exponential phase were unable to degrade cyanide, whereas late exponential/early stationary phase cells were able to do so (Fig. 2). The addition of $20 \mathrm{mg}$ cyanide $\mathrm{l}^{-1}$ to the medium did not induce the cyanide-degrading activity in lag-or exponential-phase cells.

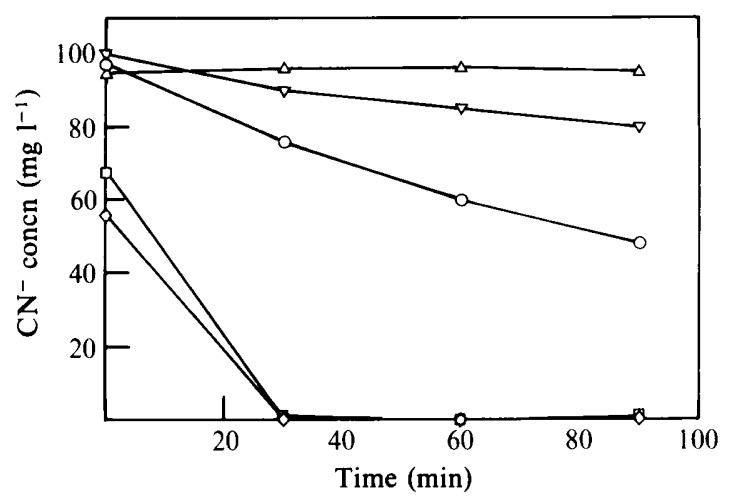

Fig. 3. Effect of $\mathrm{Mn}^{2+}$ in the growth medium on cyanide degradation by cells of $B$. pumilus $\mathrm{C}$. Cells were grown at $30^{\circ} \mathrm{C}$ with shaking for $14 \mathrm{~h}$ in Oxoid nutrient broth $(20 \mathrm{ml})$ containing increasing concentrations of $\mathrm{Mn}^{2+}$. Cultures were harvested by centrifugation and resuspended in standard containers containing $10 \mathrm{ml}$ sterile distilled water and $100 \mathrm{mg}$ $\mathrm{CN}^{-} 1^{-1}$ without added $\mathrm{Mn}^{2+}(\mathrm{pH} 10 \cdot 5)$. The suspensions were incubated at $30^{\circ} \mathrm{C}$ without shaking and the cyanide concentrations were assayed at $30 \mathrm{~min}$ intervals for $1.5 \mathrm{~h} . \mathrm{Mn}^{2+}$ concentration $\left(\mathrm{mg} \mathrm{l}^{-1}\right)$ in the growth medium: $0(\nabla) ; 0.002(\bigcirc) ; 0.01(\square) ; 0.05(\diamond) . \triangle$, Control (cyanide + water). The SEM values were $5-10 \%$ of the values in the Figure (three determinations were done).

B. pumilus cells grown in Oxoid nutrient broth made with Millipore deionized water were unable to degrade cyanide, whereas cells grown in Oxoid nutrient broth made with tap water rapidly degraded cyanide. An investigation of the elements present in the tap water showed that manganese was specifically required in the growth medium for the production of the cyanidedegrading activity of the $B$. pumilus cells. The addition of $0.01 \mathrm{mg} \mathrm{Mn} \mathrm{Mn}^{2+1}$ to Oxoid nutrient broth made with Millipore deionized water resulted in the production of cyanide-degrading activity (Fig. 3). The cyanide-degrading activity was not produced when cells were grown at $\mathrm{Mn}^{2+}$ concentrations below $0.002 \mathrm{mg}^{1-1}$. The presence or absence in the growth medium of the other elements shown to be present in tap water did not affect the cyanide-degrading ability of the $B$. pumilus cells (results not shown). Manganese may be required either for induction of the gene(s) controlling cyanide-degrading enzyme activity, or as a component of the cyanidedegrading enzyme activity.

Cell-free extracts were diluted to a concentration of $0.2 \mathrm{mg}$ protein $\mathrm{ml}^{-1}$ and assayed for their ability to degrade cyanide. The cell-free extracts degraded cyanide efficiently and the specific activity for cyanide degradation was $0.28 \mu \mathrm{mol} \mathrm{CN}^{-}$used $\mathrm{min}^{-1}$ (mg protein) $)^{-1}$. The cyanide-degrading activity of the cell-free extracts appeared to be stable and could be stored at $4{ }^{\circ} \mathrm{C}$ or $-20^{\circ} \mathrm{C}$ without loss of activity. Degradation of cyanide by cell-free culture supernatants was not detected.

Since $B$. pumilus $\mathrm{Cl}$ yielded crude cell extracts which 
were relatively stable and degraded cyanide efficiently after storage, this strain has potential in the development of a cell-free biological treatment system. The absolute requirement for $\mathrm{Mn}^{2+}$ for the production of the cyanidedegrading activity appears to be a specific characteristic of $B$. pumilus $\mathrm{Cl}$.

\section{References}

CASTRIC, P. A. \& ConN, E. E. (1971). Formation of beta-cyanoalanine by $O$-acetylserine sulfhydrylase. Journal of Bacteriology 108, 132-136.

Castric, P. A. \& Strobel, G. A. (1969). Cyanide metabolism by Bacillus megaterium. Journal of Biological Chemistry 244, 4089-4094.

Cruickshank, R., Duguid, J. P., Marmion, B. P. \& Swain, R. H. A. (editors) (1975). Tests for identification of bacteria. In Medical Microbiology, vol. 2, The Practice of Medical Microbiology, 12th edn, pp. 170-189. Edinburgh: Churchill Livingstone.

DORR, P. K. \& KNOwLES, C. J. (1989). Cyanide oxygenase and cyanase activities of Pseudomonas fluorescens NCIMB 11764. FEMS Microbiology Letters 60, 289-294.

Fisher, F. B. \& Brown, J. S. (1952). Colorimetric determination of cyanide in stack gas and waste water. Analytical Chemistry 24, 14401444

GoRDON, R. E. (1973). The genus Bacillus. In CRC Handbook of Microbiology, vol. I, pp. 71-88. Edited by A. I. Laskin \& H. A. Lechevalier. Cleveland, Ohio, USA: CRC Press.

HARRIS, R. \& KNOWLES, C. J. (1983a). Isolation and growth of a Pseudomonas species that utilizes cyanide as a source of nitrogen. Journal of General Microbiology 129, 1005-1011.

HARRIS, R. E. \& K NOWLES, C. J. (1983b). The conversion of cyanide to ammonia by extracts of a strain of Pseudomonas fluorescens that utilizes cyanide as a source of nitrogen for growth. FEMS Microbiology Letters 20, 337-341.

ICI BIOPRODUCTs. (1987). Production of cyanide hydratase. European Patent Application no. 87300840.3
Knight, B. C. J. G. \& Proom, H. (1950). A comparative survey of the nutrition and physiology of mesophilic species in the genus Bacillus. Journal of General Microbiology 4, 508-538.

KNOWLES, C. J. \& BUNCH, A. W. (1986). Microbial cyanide metabolism. Advances in Microbial Physiology 27, 73-111.

McFeters, G. A., Wilson, D. F. \& Strobel, G. A. (1970). Cytochromes in a cyanide-resistant strain of Bacillus cereus. Canadian Journal of Microbiology 16, 1221-1226.

MUDDER, T. I. (1989). The chemistry of the cyanidation process. In The Chemistry, Analysis, Toxicity, and Treatment of Cyanidation Wastewaters. Society of Mining Engineers Conference, Las Vegas, Nevada 1989, pp. 1.1-1.18. Edited by T. I. Mudder.

NorRis, J. R., Berkeley, R. C. W., Logan, N. A. \& O'DonNell, A. G. (1981). The genera Bacillus and Sporolactobacillus. In The Prokaryotes: a Handbook on Habitats, Isolation and Identification of Bacteria, vol. II, pp. 1711-1742. Edited by M. P. Starr, H. Stolp, H. G. Trüper, A. Balows \& H. G. Schlegel. Berlin : Springer-Verlag.

Novo-NoRDisK A/S. (1989). Process for decomposition of metal-cyano complexes using microbial enzymes. Official Patent Application (South Africa) no. 894989

Rollinson, G., Jones, R., Meadows, M. P., Harris, R. E. \& KNOWLES, C. J. (1987). The growth of a cyanide-utilizing strain of Pseudomonas fluorescens in liquid culture on nickel cyanide as a source of nitrogen. FEMS Microbiology Letters 40, 199-205.

Skowronski, B. \& Strobel, G. A. (1969). Cyanide resistance and utilization by a strain of Bacillus pumilus. Canadian Journal of Microbiology 15, 93-98.

SNEATH, P. H. A. (1986). Endospore-forming Gram-positive rods and cocci. In Bergey's Manual of Systematic Bacteriology, vol. 2, pp. 1104 1207. Edited by P. H. A. Sneath, N. S. Mair, M. E. Sharpe \& J. G Holt. Baltimore: Williams \& Wilkins.

White, J. M., Jones, D. D., Huang, D. \& Gauthier, J. J. (1988). Conversion of cyanide to formate and ammonia by a pseudomonad obtained from industrial wastewater. Journal of Industrial Microbiology 3, 263-272.

WhitLOCK, J. L. \& MUdDER, T. I. (1986). The Homestake wastewater treatment process: biological removal of toxic parameters from cyanidation wastewaters and bioassay effluent evaluation. In Fundamental and Applied Biohydrometallurgy, pp. 327-337. Edited by R. W. Lawrence, R. M. R. Branion \& H. G. Ebner. Amsterdam: Elsevier. 